Branimir Kalaš $\check{1}^{1}$

Vera Miroviće

Jelena Andrašić ${ }^{3}$

University of Novi Sad, Faculty of Economics Subotica
SCIENTIFIC REVIEW ARTICLE doi:10.5937/ekonomika1802099K

Received November, 01, 2017

Accepted: March, 1, 2018

\title{
EMPIRICAL ANALYSIS OF VALUE ADDED TAX AND INFLATION RATE: TUCKEY'S HSD TEST IN SELECTED WESTERN BALKAN COUNTRIES
}

\begin{abstract}
In economic theory the price movement at a general level is one of the essential issues that can significantly affect on economic flows. The aim of this paper is to show that there is a significant difference in the average price level in the countries of the region, where the value added tax rates are analysed at the same time. The subject of the paper is manifested by the reflection of the inflation rate and value added tax rate in seven countries in the region from 2008 to 2016. Selected countries are Serbia, Albania, Bosnia and Herzegovina, Croatia, Macedonia, Montenegro and Slovenia. Based on the graph, it was found that in the years when there was a growth of value added tax, the inflation rate was declined which means there is no positive impact of tax form on inflation ie. there is a reduction of the inflation rate. Also, bearing in mind fact that inflation rate is not primarily caused by the movement of value added tax rate, authors have focused on determining the difference between average inflation rate in observed countries. Using ANOVA and Tuckey's HSD test, it is determined a statistically significant difference between all countries in the group, while in the case of Serbia, it can notice there is a statistically significant difference between other countries in the region, except for Montenegro, where there is no statistical significance.
\end{abstract}

Key words: inflation, value added tax, ANOVA, Tuckey'S HSD test, Western Balkan

JEL classification: C01, E31, H2

\section{ЕМПИРИЈСКА АНАЛИЗА ПОРЕЗА НА ДОДАТУ ВРЕДНОСТ И СТОПЕ ИНФЛАЦИЈЕ: ТUСКЕУ'S НSD ТЕСТ У ОДАБРАНИМ ЗЕМЉАМА ЗАПАДНОГ БАЛКАНА}

\begin{abstract}
Апстракт
У економској теорији кретање цена на општем нивоу представља једно од важних питаға које могу значајно утицати на економске токове. Циљ овог рада је приказати да постоји значајна разлика у кретану просечног нивоа цена у земьама у региону, где су истовремено анализиране стопе пореза на додату вредност. Предмет рада је манифестован кроз приказ стопе инфлаџије и стопе
\end{abstract}

\footnotetext{
${ }^{1}$ branimir.kalas@ef.uns.ac.rs

²vera.mirovic@ef.uns.ac.rs

3jelenadj@ef.uns.ac.rs
} 
пореза на додату вредност у седам земаља у региону од 2008 до 2016 године. Посматране земље су: Србија, Албанија, Босна и Хериеговина, Хрватска, Македонија, Црна Гора и Словенија. На основу графичких приказа утврђено је да у годинама када је дошло до раста стопе пореза на додату вредност, стопа инфлације је опадала, ито подразумева да не постоји позитиван утицај пореског облика на инфлаиију, тј. присутно је смањење стопе инфлачије. Такође, уважсавајући чињенииу да инфлачија није примарно условљена кретањем пореза на додату вредност, аутори су се фокусирали на детерминисање разлика између просечне стопе инфлачије у посматраним земьама. Користећи АНОВА u Tuckey's HSD тест, утврђено је да постоји статистички значајна разлика између свих земаља у групи, док је у случају Србије присутна статистички значајна разлика између осталих земаља у региону осим Црне Горе где није утврђена статистичка значајност.

Кључне речи: инфлација, порез на додату вредност, АНОВА, Туцчкеу'С ХСД тест, Западни Балкан

\section{Introduction - Theoretical background}

In modern government, taxes have an important place in their programs and they are a powerful tool for achieving main goals in the economy. Stojanović and Đorđević (2016) argue that taxes are the most essential public revenue of all modern states. Kalaš and Milenković (2017) point out that tax effects on economic activity is one of the main area of public finance. Grun (2000) defined a tax as mandatory statutory payment collected by the state, municipalities or other public entities for covering public needs while Karolak (2011) determined tax as a compulsory payment created by the government of a country from that main products and services are performed. Gatawa et al. (2016) determine the taxes as one of the most important revenue generation mechanisms in every economy. They are used to achieve economic growth and equity in income and wealth distribution, while on the other hand, their characteristics are reliability and predictability. The biggest share of the state budget revenues has taxes and their total share should be $50 \%$ to $80 \%$ (Mankiw et al. 2009). By definition of Netherlands Economic Institute (1998) value added presents the difference between the value of the production and the value of the goods and services which are used in the production, where VAT burden ultimately rests on the final consumers. It represents a form of consumption tax. From the buyer's perspective, it's a tax on the purchase price while from that of the seller, it's a tax only on the value added to a product or services (Sivasakkaravarthi and Ganesan 2011).

Aliyzadeh and Motallabi (2016) defined value added tax as a multistep tax obtained in different steps of importing, production and distribution based on the added value of the sold goods and delivered services. A value added tax is less distortionary than other tax forms (Auerbach 2008; Banks and Diamond 2010; Claus 2013). Inflation represents an important indicator in the economy and there are many determinants whose effect to her. Anbarci (2015) determined inflation tax as a phenomenon when prices increase and the real value of individual's money holdings decreases. When it looks taxes, value added tax presents the most used tax form which can have an impact on inflation. There are many studies that researched relationship between value added tax and inflation (Katz and Rosen 1985; Stern 1987; Poterba and Rotemberg 1990; Bayoumi and Gagnon 1992; Besley 
1999; Mankiw and Reiss 2002, Caballe and Panades 2004; Carbonnier 2007; Carare and Danninger 2008; Gabriel and Reiff, 2010; Miki 2011; Benkovskis et al. 2012; Benkovskis and Fadejeva, 2014). Poterba and Rotemberg (1990) reported a positive relationship between inflation and tax rates in the United States, as well as the fact that government uses these components to increase revenues in the budget. Benkovskis and Fadejeva (2014) examined the effect of value added tax rate on inflation in Latvia using the CPI microdata provided by the Central Statistical Bureau of Latvia. They argued that changes in the VAT rate could have an important implication for inflation, especially at the moments of VAT rate revisions. Using panel data models for 14 developed countries from the second quarter in 1980 to the third quarter in 2010, Miki (2011) reflects that aggregate consumption and economic growth display three trends when the value added tax rate is changed, where they increase or decrease just before the rise or reduction of the VAT rate.

Figure 1. The movement of aggregate consumption - increase of VAT rate

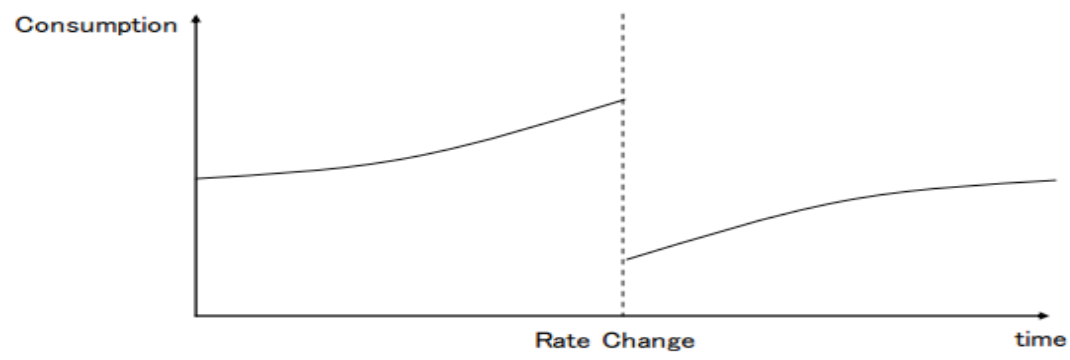

Source: Miki (2011)

Figure 2. The movement of aggregate consumption - decrease of VAT rate

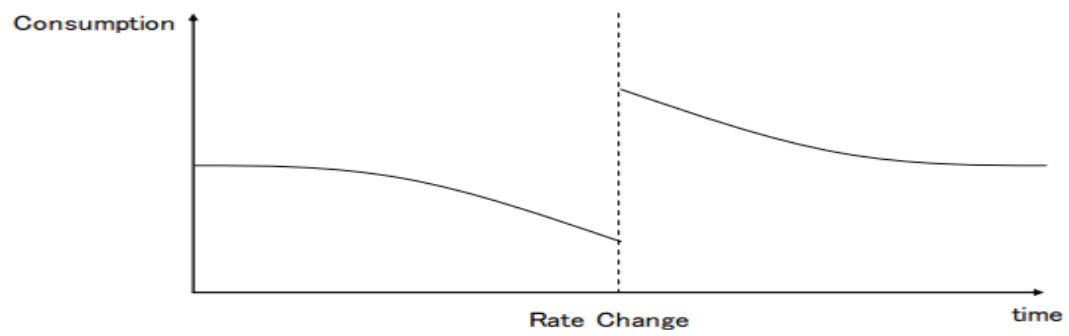

Source: Miki (2011)

In theory, if there is an announcement that the government will increase the VAT rate, people will buy things which may store before increasing this tax form. After its increase, aggregate consumption will decline because people will use the reserves of previously purchased products instead of buying new items. Furthermore, aggregate consumption will gradually grow as people used these things and have no need for new items. 


\section{Value added tax and inflation in Western Balkan countries}

This chapter of paper is focused on a historical review of the introduction of value added tax and inflation rate in selected countries and also it's presented their trends rate from 2008 to 2016.

Figure 3. Review of VAT introduction by country

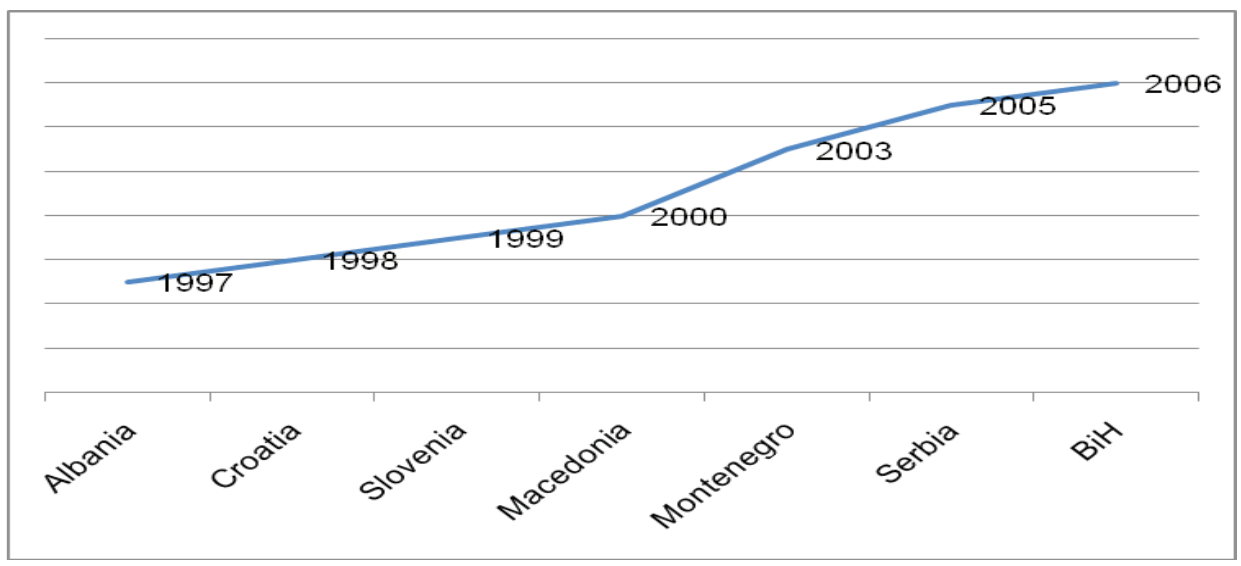

Source: Author based on http://eurofast.eu

Figure 3 reflects a historical overview of the introduction of VAT rates in the countries in the region. Bearing in mind that France was the first country which introduced this tax form in 1954 (Shenk and Oldman 2007), there is a noticeable time lag in relation to the countries in this region. Namely, Albania, Croatia, and Slovenia have succeeded to modernize their tax systems by introducing value added tax before 2000, while other countries take much more time for this step. This applies particularly to Serbia and Bosnia and Herzegovina which have recently introduced VAT in 2005 and 2006.

Table 1. Review of VAT registration threshold in 2016

\begin{tabular}{|l|l|l|}
\hline Country & Per year & Amount \\
\hline Albania & Turnover for the last 12 months & 5.000 .000 ALL \\
\hline Bosnia and Herzegovina & Turnover for the last 12 months & 50.000 BAM \\
\hline Croatia & Turnover for the last 12 months & 230.000 HRK \\
\hline Macedonia & Turnover for the last 12 months & 1.000 .000 MKD \\
\hline Montenegro & Turnover for the last 12 months & 18.000 EUR \\
\hline Serbia & Turnover for the last 12 months & 8.000 .000 RSD \\
\hline Slovenia & Turnover for the last 12 months & 35.000 EUR \\
\hline
\end{tabular}

Source: Author based on http://eurofast.eu 
Figure 4. Trend of inflation rate in observed countries

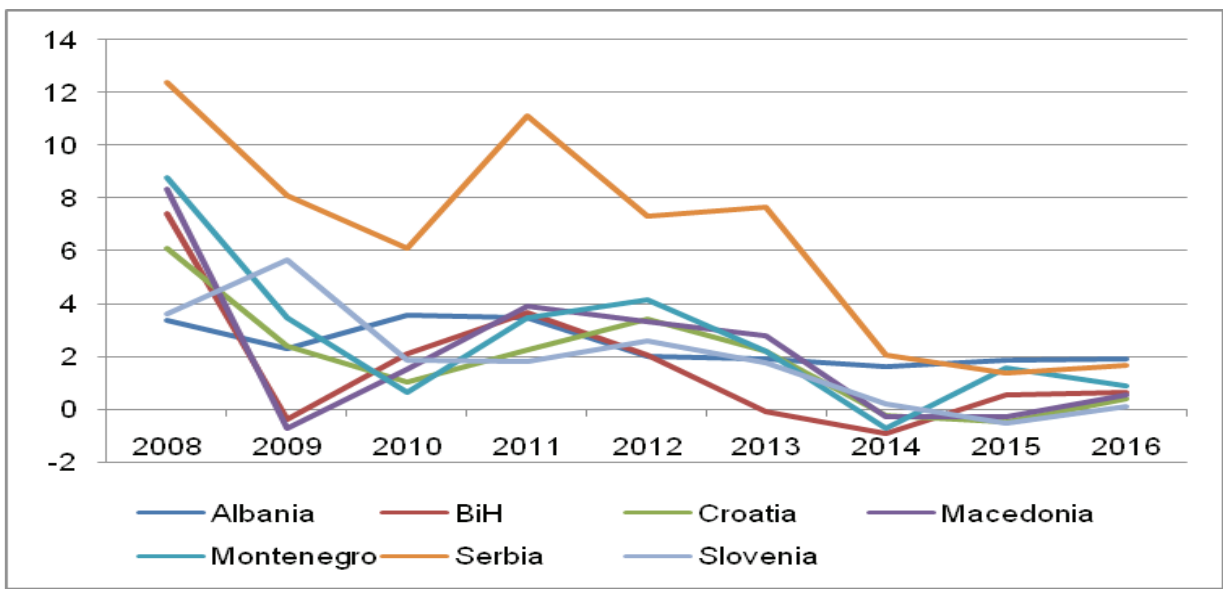

Source: Author based on www.imf.com.

Looking at a price level in the countries in the region, it can see that the highest inflation rate is in Serbia during the whole period. This is especially evident in the period from 2008 to 2011, when the average inflation rate in Serbia amounted 9.45\%, provided that at the beginning of the period recorded a maximum inflation rate of $12.41 \%$. In other countries for the same period, the average inflation rate ranged from $2 \%$ to $3 \%$. If it compares the price level for the last three years, Albania had the highest average inflation rate of $1.82 \%$, while Macedonia recorded a decrease of the general level of price by an average of $0.01 \%$.

Figure 5. Value added tax rate in observed countries

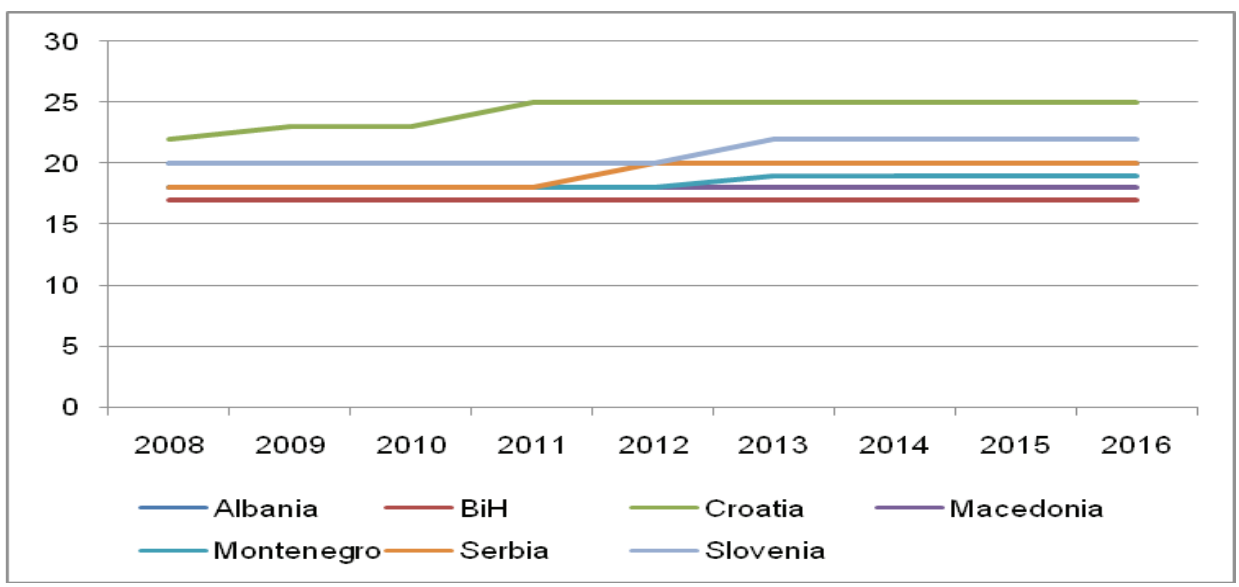

Source: Author based on www.kpmg.com.

Figure 5 shows the movement of standard VAT rates in the countries in the region for the period 2008-2016. As can be seen, Croatia has the highest rate of $25 \%$ while on the other hand, Bosnia and Herzegovina has the lowest rate of $17 \%$. When it comes to 
the constancy of the VAT rate, it didn't change in Albania, Bosnia and Herzegovina and Macedonia and it remained the same during the observed period. In other countries, there has been an increase in the VAT rate by $1 \%$ or $2 \%$ as is the case in Montenegro, Serbia, and Slovenia, while Croatia recorded the highest increase in the VAT rates, there has been an increase in the VAT rate by $1 \%$ or $2 \%$ as is the case in Montenegro, Serbia and Slovenia, while Croatia recorded the highest increase in the VAT rate of $3 \%$ from the beginning to the end of the period.

\section{Results}

The aim of this paper is estimating the impact of value added tax on inflation in seven observed countries from 2008 to 2016. The author used the database from International Monetary funds for inflation and KPMG for value added tax rate for selected countries: Serbia, Albania, Bosnia and Herzegovina, Croatia, Macedonia, Montenegro, and Slovenia. First, it's reflected descriptive statistics.

Table 2. Descriptive statistics

\begin{tabular}{|c|c|c|c|c|c|c|c|c|}
\hline \multirow{2}{*}{ Country } & \multirow{2}{*}{$\mathrm{N}$} & \multirow{2}{*}{ Mean } & \multirow{2}{*}{ Std. Dev. } & \multirow{2}{*}{ Std. Error } & \multicolumn{2}{|c|}{$\begin{array}{l}\text { 95\% Confidence } \\
\text { Interval for Mean }\end{array}$} & \multirow[t]{2}{*}{ Minimum } & \multirow{2}{*}{ Maximum } \\
\hline & & & & & $\begin{array}{l}\text { L o w e r } \\
\text { Bound }\end{array}$ & $\begin{array}{l}\mathrm{U} p \mathrm{p} \text { e } \mathrm{r} \\
\text { Bound }\end{array}$ & & \\
\hline Serbia & 9 & 6.4400 & 4.03468 & 1.34489 & 3.3387 & 9.5413 & 1.39 & 12.41 \\
\hline Albania & 9 & 2.4511 & .77143 & .25714 & 1.8581 & 3.0441 & 1.63 & 3.55 \\
\hline $\mathrm{BiH}$ & 9 & 1.6844 & 2.58833 & .86278 & -.3051 & 3.6740 & -.90 & 7.43 \\
\hline Croatia & 9 & 1.9022 & 2.03871 & 67957 & .3351 & 3.4693 & -.46 & 6.08 \\
\hline Macedonia & 9 & 2.1200 & 2.87830 & .95943 & -.0925 & 4.3325 & -.74 & 8.33 \\
\hline Montenegro & 9 & 2.7122 & 2.75274 & 2.75274 & .5963 & 4.8282 & -.71 & 8.76 \\
\hline Slovenia & 9 & 1.8956 & 1.91893 & 63964 & .4205 & 3.3706 & -.52 & 5.65 \\
\hline Total & 63 & 2.7437 & 2.91930 & .36780 & 2.0084 & 3.4789 & -.90 & 12.41 \\
\hline
\end{tabular}

Source: Author based on SPSS

As it can see, the largest average inflation was recorded in Serbia and it amounts to $6.44 \%$ which is almost three times more than the average inflation in the observed group of countries. Similarly, the largest standard deviation is presented in Serbia of 4.03468 which is nearly double the total standard deviation. This can be attributed to a wide range of minimum and maximum rates of inflation in Serbia, where it ranged from $1.39 \%$ to $12.41 \%$. Looking at the other countries, the average inflation rate is the lowest in Bosnia and Herzegovina, Slovenia and Croatia which didn't exceed 2\%, while it's at a level of 2.5-2.7\% in Albania, Macedonia and Montenegro.

Table 3. ANOVA test

\begin{tabular}{|l|r|r|r|r|r|}
\hline & Sum of Squares & df & Mean Square & F & Sig. \\
\hline Between Groups & 150.189 & 6 & 25.032 & 3.706 & .004 \\
Within Groups & 378.192 & 56 & 6.753 & & \\
Total & 378.192 & 62 & & & \\
\hline
\end{tabular}

Source: Author based on SPSS 
Testing the null hypothesis of significance, results reflect that there is a statistically significant difference among the observed countries $(p=0.004<0.05)$. After that, authors used multiple comparisons procedure and statistical test Tukey's HSD test to find means which are significantly different from each other.

Table 4. Multiple Comparisons - Tuckey's HSD test

\begin{tabular}{|c|c|c|c|c|c|c|}
\hline \multirow[b]{2}{*}{ (I) Countries } & \multirow[b]{2}{*}{ (J) Countries } & \multirow{2}{*}{$\begin{array}{c}\text { Mean } \\
\text { Difference } \\
(\mathrm{I}-\mathrm{J})\end{array}$} & \multirow[b]{2}{*}{$\begin{array}{l}\text { Std. } \\
\text { Error }\end{array}$} & \multirow[b]{2}{*}{ Sig. } & \multicolumn{2}{|c|}{ 95\% Confidence Interval } \\
\hline & & & & & $\begin{array}{l}\text { Lower } \\
\text { Bound }\end{array}$ & $\begin{array}{l}\text { Upper } \\
\text { Bound }\end{array}$ \\
\hline \multirow{6}{*}{ Serbia } & Albania & $3.98889^{*}$ & 1.22506 & .030 & .2427 & 7.7351 \\
\hline & $\mathrm{BiH}$ & $4.75556^{*}$ & 1.22506 & .005 & 1.0093 & 8.5018 \\
\hline & Croatia & $4.53778^{*}$ & 1.22506 & .008 & .7915 & 8.2840 \\
\hline & Macedonia & $4.32000^{*}$ & 1.22506 & .014 & .5738 & 8.0662 \\
\hline & Montenegro & 3.72778 & 1.22506 & .052 & -.0185 & 7.4740 \\
\hline & Slovenia & $4.54444^{*}$ & 1.22506 & .008 & .7982 & 8.2907 \\
\hline \multirow{6}{*}{ Albania } & Serbia & $-3.98889^{*}$ & 1.22506 & .030 & -7.7351 & -.2427 \\
\hline & $\mathrm{BiH}$ & .76667 & 1.22506 & .996 & -2.9796 & 4.5129 \\
\hline & Croatia & .54889 & 1.22506 & .999 & -3.1973 & 4.2951 \\
\hline & Macedonia & .33111 & 1.22506 & 1.000 & -3.4151 & 4.0773 \\
\hline & Montenegro & -.26111 & 1.22506 & 1.000 & -4.0073 & 3.4851 \\
\hline & Slovenia & .55556 & 1.22506 & .999 & -3.1907 & 4.3018 \\
\hline \multirow{6}{*}{$\mathrm{BiH}$} & Serbia & $-4.75556^{*}$ & 1.22506 & .005 & -8.5018 & -1.0093 \\
\hline & Albania & -.76667 & 1.22506 & .996 & -4.5129 & 2.9796 \\
\hline & Croatia & -.21778 & 1.22506 & 1.000 & -3.9640 & 3.5285 \\
\hline & Macedonia & -.43556 & 1.22506 & 1.000 & -4.1818 & 3.3107 \\
\hline & Montenegro & -1.02778 & 1.22506 & .980 & -4.7740 & 2.7185 \\
\hline & Slovenia & -.21111 & 1.22506 & 1.000 & -3.9573 & 3.5351 \\
\hline \multirow{6}{*}{ Croatia } & Serbia & $-4.53778^{*}$ & 1.22506 & .008 & -8.2840 & -.7915 \\
\hline & Albania & -.54889 & 1.22506 & .999 & -4.2951 & 3.1973 \\
\hline & $\mathrm{BiH}$ & .21778 & 1.22506 & 1.000 & -3.5285 & 3.9640 \\
\hline & Macedonia & -.21778 & 1.22506 & 1.000 & -3.9640 & 3.5285 \\
\hline & Montenegro & -.81000 & 1.22506 & .994 & -4.5562 & 2.9362 \\
\hline & Slovenia & .00667 & 1.22506 & 1.000 & -3.7396 & 3.7529 \\
\hline \multirow{6}{*}{ Macedonia } & Serbia & $-4.32000^{*}$ & 1.22506 & .014 & -8.0662 & -.5738 \\
\hline & Albania & -.33111 & 1.22506 & 1.000 & -4.0773 & 3.4151 \\
\hline & $\mathrm{BiH}$ & .43556 & 1.22506 & 1.000 & -3.3107 & 4.1818 \\
\hline & Croatia & .21778 & 1.22506 & 1.000 & -3.5285 & 3.9640 \\
\hline & Montenegro & -.59222 & 1.22506 & .999 & -4.3385 & 3.1540 \\
\hline & Slovenia & .22444 & 1.22506 & 1.000 & -3.5218 & 3.9707 \\
\hline \multirow{6}{*}{ Montenegro } & Serbia & -3.72778 & 1.22506 & .052 & -7.4740 & .0185 \\
\hline & Albania & .26111 & 1.22506 & 1.000 & -3.4851 & 4.0073 \\
\hline & $\mathrm{BiH}$ & 1.02778 & 1.22506 & .980 & -2.7185 & 4.7740 \\
\hline & Croatia & .81000 & 1.22506 & .994 & -2.9362 & 4.5562 \\
\hline & Macedonia & .59222 & 1.22506 & .999 & -3.1540 & 4.3385 \\
\hline & Slovenia & .81667 & 1.22506 & .994 & -2.9296 & 4.5629 \\
\hline
\end{tabular}




\begin{tabular}{|l|l|r|r|r|r|r|}
\hline \multirow{5}{*}{ Slovenia } & Serbia & $-4.54444^{*}$ & 1.22506 & .008 & -8.2907 & -.7982 \\
\cline { 2 - 7 } & Albania & -.55556 & 1.22506 & .999 & -4.3018 & 3.1907 \\
\cline { 2 - 7 } & BiH & .21111 & 1.22506 & 1.000 & -3.5351 & 3.9573 \\
\cline { 2 - 7 } & Croatia & -.00667 & 1.22506 & 1.000 & -3.7529 & 3.7396 \\
\cline { 2 - 7 } & Macedonia & -.22444 & 1.22506 & 1.000 & -3.9707 & 3.5218 \\
\cline { 2 - 7 } & Montenegro & -.81667 & 1.22506 & .994 & -4.5629 & 2.9296 \\
\hline
\end{tabular}

*. The mean difference is significant at the 0.05 level.

Source: Author based on SPSS

Table 4 manifests the difference between the average values of the inflation rate for the observed group of selected countries. Looking a the value for Serbia, it's evident that there is a significant difference compared to other countries, apart from Montenegro where there is no significant difference on the basis of $p$-value $(0.052>0.05)$. The highest difference between the average value was recorded between Serbia and Bosnia and Herzegovina, where it is 4.7556 which is slightly more compared with the Croatia, Macedonia, and Slovenia, where it is also above 4. Considering that the total value of the observed countries, the average inflation rate is almost three times higher in Serbia than the average of other countries. On the other hand, if we exclude Serbia from the analyzed group, there is a difference between the average inflation rate, but it's not statistically significant.

\section{Conclusion}

Inflation is one of the two most important macroeconomic phenomena in addition to the gross domestic product. It depends on a number of determinants, and one of the reasons for an increase in the level of prices on the general level and greater inflationary risks can be value added tax. This tax form represents on the most abundant forms of taxation in the countries in the region. Observing the tax rates in the region, it's showed that Albania, Bosnia and Herzegovina and Macedonia didn't change rates in the analyzed period, while other countries had increased value-added tax rates. It's noticeable that in the years when it came to the increase of this tax form in these countries, inflation rate declining. Thus it can be concluded that the value added tax doesn't have a positive effect on the inflation rate in terms of its growth. However, using ANOVA test and Tuckey's HSD test, it was found out a significant difference in terms of the average inflation rates between countries. The results showed that there is a statistically significant difference between the average values of the inflation between countries, where if we look only Serbia, it has been found that the average inflation rate is significantly different compared to all the countries in the region, except Montenegro, where it has been established that there is no significant difference in terms of this indicator. Future research will be focused on the creation of regression model of inflation and including more independent variable how it would be easy to get an answer on a question which variables have a significant impact on inflation. 


\section{References}

Alizadeh, M., Motallabi, M. (2016), Studying the effect of value added tax on the size of current government and construction government, Procedia Economics and Finance, Vol. 36, pp. 336-344. DOI:10.1016/S2212-5671(16)30045-4

Anbarci, N., Dutu, R., Feltovich, N. (2015), Inflation tax in the lab: a theoretical and experimental study of competitive search equilibrium with inflation, Journal of Economic Dynamics \& Control, Vol. 61, pp. 17-33. DOI:10.1016/j. jedc.2015.09.005

Auerbach, A.J. (2008), Tax Reform in the Twenty-First Century. In: Diamond, J.W., Zodrow, G.R. (Eds.). Fundamental Tax Reform: Issues, Choices and Implications. The MIT Press, Cambridge, pp. 27-74.

Banks, J.W., Diamond, P.A. (2010), The Base for Direct Taxation, In: Institute for Fiscal Studies (Eds.). Dimension of Tax Design. Oxford University Press, New York, pp. 548-648.

Bayoumi, T., Gagnon, J. (1992), Taxation and Inflation: A New Explanation for Current Account Imbalances, Board of Governors of the Federal Reserve System, International Finance Discussion Papers 420.

Benkovskis, K., Fadejeva, L., Kalnberzina, K. (2012), Price setting behaviour in Latvia: Econometric evidence from CPI micro data, Economic Modelling, Vol. 29, No. 6, pp. 2115-2124. DOI:10.1016/j.econmod.2012.07.003

Benkovskis, K., Fadejeva, L. (2014), The effect of VAT rate on inflation in Latvia: evidence from CPI microdata, Applied Economics, Vol. 46, No. 21, pp. 25202533.

Besley, T.J., Rosen, H.S. (1999), Sales Taxes and Prices: An Empirical Analysis, National Tax Journal, Vol. 52, No. 2, pp. 157-178.

Caballe, J., Panades, J. (2004), Inflation, tax evasion, and the distribution of consumption, Journal of Macroeconomics, Vol. 26, pp. 567-595, DOI:10.1016/j. jmacro.2003.06.001.

Carbonnier, C. (2007), Who Pays Sales Taxes? Evidence from French VAT reforms, 1987-1999, Journal of Public Economics, Vol. 91, pp. 1219-1229.

Carare, A., Danninger, S. (2008), Inflation Smoothing and the Modes Effect of VAT in Germany, International Monetary Fund, IMF Working Paper WP 08/175.

Cashin, D., Takashi, U. (2011), The Intertemporal Substitution and Income Effects of a VAT Rate Increase: Evidence from Japan, Discussion papers from Research Institute of Economy, Trade and Industry.

Christandl, F., Fetchenhauer, D., Hoelzl, E. (2011), Price percpetion and confirmation bias in the context of a VAT increase? Journal of Economic Psychology, Vol. 32, pp. 131-141. DOI: 10.1016/j.joep.2010.09.006

Claus, I. (2013), Is the value added tax a useful macroeconomic stabilization instrument? Economic Modelling, Vol. 30, pp. 366-374. DOI: 10.1016/j. econmod.2012.08025. 
Gabriel, P., Reiff, A. (2010), Price setting in Hungary - a store-level analysis, Managerial and Decision Economics, Vol. 31, pp. 161-176. DOI:10.1002/mde.1479

Gatawa, N.M., Aliero, H.M., Aishatu, A.M. (2016), Evaluating the impact of value added tax on the economic growth of Nigeria, Journal of Accounting and Taxation, Vol. 8, No. 6, pp. 59-65. DOI: 10.5897/JAT2016.0226

Gelardi, A. (2014), Value Added Tax and Inflation: A Graphical and Statistical Analysis, Asian Journal of Finance \& Accounting, Vol. 6, No. 1, pp. 138-158. DOI:10.5296/ajfa.v6i1.5065

Grun, L. (2000), Dejiny dani, poplatkov a cla. Bratislava: Holoprint, 156 s. Pravnik, Teoreticky časopis pro otazkz statu a prava.

Ikpe, M., Nteegah, A. (2013), Value Added Tax and price stability in Nigeria: A partial equilibrium analysis, European Journal of Government and Economics, Vol. 2, No. 3, pp. 137-147.

Izedonmi, F.I.O., Okunbor, J.A. (2014), The Roles of Value Added Tax in the Economic Growth of Nigeria. British Journal of Economics, Management \& Trade, Vol. 4, No. 12, pp. 1999-2007

Kalaš, B., Milenković, N. (2017), The role of value added tax in the economy of Serbia, Ekonomika, Vol. 63, No. 2, pp. 69-78.

Karolak, A. (2011), Adaption Process of a Polish Tax Law to European Union Norms Harmonization of a Value Added Tax, Economics and Sociology, Vol. 4, No. 1, pp. 54-63.

Katz, M.L., Rosen, H.S. (1985), Tax Analysis in an Oligopoly Model, Public Finance Quarterly, Vol. 13, No. 1, pp. 3-19.

Mankiw, G., Reis, R. (2002), Sticky Information Versus Sticky Prices: A Proposal to Replace the New Keynesian Phiillips Curve, Quarterly Journal of Economics, Vol. 4, No. 117, pp. 1295-1328.

Mankiw, G., Weinzierl, M., Yagan, D. (2009), Optimal Taxation in Theory and Practice, Journal of Economic Perspectives, American Economic Association, Vol. 23, No. 4, pp. 147-174.

Miki, B. (2011), The Effect of the VAT Rate Change on Aggregate Consumption and Economic Growth, Columbia University, Center on Japanese Economy and Business, Working Paper Series 297.

Netherlands Economic Institute (1998), The social consequences of changes in VAT, Economic Affairs Series, European Parliament, ECON 103, Working 5.

Pike, R., Lewis, M., Turner, D. (2009), Impact of VAT reduction on the consumer price indices, Economic and Labour Market Review, Vol. 3, No. 8, pp. 17-22, DOI:10.1057/elmr.2009.139

Poterba, J.M., Rotemberg, J.J. (1990), Inflation and Taxation with Optimizing Governments, Journal of Money, Credit and Banking, Vol. 22, No. 1, pp. 1-18.

Schall, L. (1984), Taxes, Inflation and Corporate Financial Policy, The Journal of Finance, Vol. 39, No. 1, pp. 105-126. DOI:10.1111/j.1540-6261.1984.tb03863.x

Shenk, A., Oldman, O. (2007), Value Added Tax: A comparative Approach. New York: Cambridge University Press.

Sivasakkaravarthi, P., Ganesan, D. (2011), A Study on Literature Review on Value Added Tax, International Journal of Business Management, Economics and Information Technology, Vol. 3, No. 2, pp. 309-316. 
Stern, N. (1987), The effects of taxation price control and government contracts in oligopoly and monopolistic competition, Journal of Public Economics, Vol. 32, pp. 133-158.

Stojanović, M., Đorđević. (2016), The role of environmental taxes in Serbian tax system, Ekonomika, Vol. 62m No. 4, pp. 75-84.

www.eurofast.eu retrieved from http://eurofast.eu/global/services/indirect-tax/

www.imf.com. retrieved from https://www.imf.org/external/pubs/ft/weo/2016/01/ weodata/weoselgr.aspx

www.kpmg.com. retrieved from: https:/home.kpmg.com/xx/en/home/services/tax/ tax-tools-and-resources/tax-rates-online/indirect-tax-rates-table.html 